ETHEL WILSON

A CRITICAL BIOGRAPHY 
This page intentionally left blank 


\section{ETHEL WILSON}

A C RITICAL B I O GRA P H Y

David Stouck

UNIVERSITY OF TORONTO PRESS

Toronto Buffalo London 


\section{www.utppublishing.com}

(C) University of Toronto Press Incorporated 2003

Toronto Buffalo London

Printed in Canada

ISBN 0-8020-8741-8 (cloth)

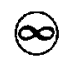

Printed on acid-free paper

\section{National Library of Canada Cataloguing in Publication}

Stouck, David, 1940-

Ethel Wilson : a critical biography / David Stouck.

Includes bibliographical references and index.

ISBN $0-8020-8741-8$

1. Wilson, Ethel, 1888-1980. 2. Novelists, Canadian (English) 2oth century - Biography. I. Title.

PS8545.162Z87 $2003 \quad$ c813'.54 C2002-905869-4

PR9199.3.W4984Z87 2003

University of Toronto Press acknowledges the financial assistance to its publishing program of the Canada Council for the Arts and the Ontario Arts Council.

This book has been published with the help of a grant from the Humanities and Social Sciences Federation of Canada, using funds provided by the Social Sciences and Humanities Research Council of Canada.

University of Toronto Press acknowledges the financial support for its publishing activities of the Government of Canada through the Book Publishing Industry Development Program (BPIDP). 
For Mary-Ann 
This page intentionally left blank 
No verbal humour ... wouldn't it be awful to live in such solemnity. - Ethel Wilson to Alan Crawley

$$
\begin{aligned}
& \text { Truth ... is opinion, of course. } \\
& \text { - Ethel Wilson to John Gray }
\end{aligned}
$$

Do we always live on a brink, then, said Nora to herself, lying there in the dark. Yes, I believe we do.

- Love and Salt Water 
This page intentionally left blank 